\title{
Supercooling and Cold-hardiness of Acclimated and Deacclimated Buds and Stems of Persian Walnut Cultivars and Selections
}

\author{
Asadolah Aslani Aslamarz, Kourosh Vahdati ${ }^{1}$, and Majid Rahemi \\ Department of Horticulture, College of Abouraihan, University of Tehran, \\ Tehran, Iran
}

\author{
Darab Hassani \\ Department of Horticulture, Seed and Plant Improvement Institute, Karaj, \\ Iran
}

\author{
Charles Leslie \\ Department of Plant Sciences, University of California, Davis, One Shields \\ Avenue, Davis, CA 95616
}

Additional index words. differential thermal analysis, freeze, injury, exotherm, Juglans regia, LTE, HTE

\begin{abstract}
To study the cold-hardiness of Persian walnut cultivars and selections, three methods were compared: 1) thermal analysis; 2) evaluation of tissue health after controlled freezing; and 3) field observations after a severe midwinter freeze. Stem segments and buds were collected from eight Persian walnut genotypes (four commercial cultivars and four promising Iranian selections). Thermal analysis was conducted using thermoelectric modules (TEM) to measure the high (HTE) and low (LTE) temperature exotherms produced when water and tissues freeze. TEM signals were recorded as the temperature of the samples was decreased at a rate of $2^{\circ} \mathrm{C} / \mathrm{h}$. Tissue injury under controlled temperatures was evaluated using pre-chilled stem segments cooled at $2{ }^{\circ} \mathrm{C} / \mathrm{h}$ to set temperatures ranging from -5 to $-30^{\circ} \mathrm{C}$ and then held at these temperatures for $16 \mathrm{~h}$. Frozen samples were thawed and visually evaluated for severity of injury. Cold damage under field conditions was evaluated after an unusually severe winter freeze. Twigs from affected trees were removed in mid-February and in April and visually rated for extent of injury and ability to recover. The occurrence of LTEs was correlated with death of the tissues as assessed by tissue browning. Both the capacity to supercool and the cold-hardiness of cultivars and selections tested increased with accumulated seasonal chilling and decreased as they approached spring budbreak. Thermal analysis showed a tendency for buds and stems to exhibit multiple LTEs at peak dormancy. The cultivars and selections were classified into three groups based on their cold-hardiness: sensitive (' $Z_{30}$ ' and 'Serr'), semihardy (' $Z_{53}$ ' and ' $\mathrm{Z}_{67}$ '), and hardy ('Lara', 'Hartley', ' $\mathrm{Z}_{63}$ ', and 'Pedro').
\end{abstract}

Low temperature is a major limiting factor in the distribution of woody plants and freeze injury is a leading cause of horticultural yield losses (Ashworth, 1992; George et al., 1974; Parker, 1963). Resistance to freeze injury changes throughout the course of the winter and is influenced by a number of factors (Quamme, 1978). During active growth, tissues have little cold tolerance but in the fall, growth stops and cold-hardiness develops. This process is called "cold acclimation" and the loss of hardiness in the spring is deacclimation. One aspect of plant cold-hardiness, known as supercooling, is the ability of cells to

\footnotetext{
Received for publication 16 Nov. 2009. Accepted for publication 4 Jan. 2010.

We thank the University of Tehran and the Iran National Science Foundation (INSF) for providing support for this research.

${ }^{1}$ To whom reprint requests should be addressed; e-mailkvahdati@ut.ac.ir.
}

limit ice formation and maintain intracellular water in liquid phase at subfreezing temperatures (Wisniewski and Arora, 2000). Supercooling plays an important role in determining the cultivation limit of native woody plants (George et al., 1974) and has been reviewed by several researchers (Bierman et al., 1979; Fujikawa and Kuroda, 2000; Pierquet et al., 1977; Quamme et al., 1995). The freezing of apoplastic water, especially that in the xylem, creates an exotherm called the HTE. This freezing does not harm the plant (Burke et al., 1976). Other observable exotherms are called LTE. The critical LTE is generally lethal for tissues. Thermal analysis and differential thermal analysis (DTA) are methods used to measure exotherms that result from freezing of tissues (Burke et al., 1976). These methods detect ice formation in the plant by using thermocouples to measure the heat released by the latent heat of fusion.

Another method of determining hardiness is to freeze plants in the laboratory and then evaluate injury by observing tissue discoloration. Usually, freeze-injured tissues develop a brown or yellowish color as a result of oxidation of polyphenols. Visual symptoms of freezing injury vary among plant species and cultivars as well as among different organs and tissues (Lapins, 1961; Malone and Ashworth, 1991; Takeda et al., 1993). The hardiness of buds or stem segments is usually estimated by subjecting the whole plant or part of it to a specific range of freezing temperatures. The cold-hardiness is then estimated by determining the temperature that kills $50 \%$ of the samples, called the LT50. The temperature at which $10 \%$ and $90 \%$ injury occurs (LT10, LT90) is an indicator of the range over which temperature injury occurs (Faust, 1989). The degree of browning after incubation provides a good estimate of the extent of injury (Stergios and Howell, 1973).

Freeze injury in trees often results from freezing temperatures in fall or after budbreak in the spring (Rodrigo, 2000). Walnut (Juglans regia L.) is grown in many regions that are susceptible to freezes that can cause injury and subsequently economic losses. Available data for the frost tolerance, supercooling, and cold acclimation of walnut cultivars and selections, especially Iranian native selections, are scarce. This study was conducted to screen a range of walnut cultivars and selections for cold-hardiness. The objectives were to: 1) determine the threshold for supercooling of buds and shoots; 2) evaluate changes in the degree of hardening before, during, and after winter; 3 ) screen cultivars and selections for cold-hardiness by exotherms, by evaluation of tissue injury under controlled conditions, and by visual observation of winter injury in an orchard; and 4) to examine the relationship between exotherms and observable tissue injury. Hence, the information obtained will provide a better understanding of how to determine the cold-hardiness of walnut and will be useful in selecting suitable genotypes for frost-prone regions.

\section{Material and Methods}

Source of plant material. One-year-old stems were randomly collected from 14-yearold trees of the commercial cultivars Serr, Pedro, Hartley, and Lara and the promising Iranian selections ' $Z_{63}$ ', ' $Z_{53}$ ', ' $Z_{30}$ ', and ' $Z_{67}$ ' grown in the Kamal Shahr $(50 \mathrm{~km}$ west of Tehran) experimental orchard of the Horticulture Department of the Seed and Plant Improvement Institute, Karaj, Iran. All the trees were grafted on Juglans regia rootstocks. The orchard is located $1312 \mathrm{~m}$ above sea level at $35.51 \mathrm{~N}, 50.51 \mathrm{E}$ and is characterized by 240 $\mathrm{mm}$ average annual rainfall, a relatively short $(\approx 2$ months $)$ dry period in the summer, cold winters (minimum temperature $-21^{\circ} \mathrm{C}$ ), and 6 months of frost danger (late November to April).

Thermal analysis. Twigs were cut from middle parts of the trees every month from Nov. 2007 to Apr. 2008, put in plastic bags, and placed in insulated containers partially filled with crushed ice for transportation to 
the laboratory. Previous studies showed that measurement of supercooling is affected by the size of the samples (Burke et al., 1976) so the twigs were cut into uniform pieces $(9 \pm 1$ cm length and $8 \pm 1 \mathrm{~mm}$ diameter) in the laboratory and the buds were excised from the twigs along with a small portion of twig tissue. A copper-constantan thermocouple (Model SMT 160; Omron Company, Tehran, Iran) was inserted into the buds and into the pith of stem segments and then wrapped in moistened cheesecloth and aluminum foil to better detection of released temperature from tissues. Dry stem pieces and buds were used as a reference to factor out temperature changes occurring in the samples during freezing.

Cooling rate can have a significant effect on the temperature at which supercooled tissues freeze (Gusta et al., 2003) and a rapid cooling rate $\left(10^{\circ} \mathrm{C} / \mathrm{hr}\right)$ would not reflect natural conditions. Therefore, samples were cooled from +5 to $-25{ }^{\circ} \mathrm{C}$ using a freezing chamber (Model MVG261; Silver Company, Tehran, Iran) programmed to cool at a rate of $-2{ }^{\circ} \mathrm{C} / \mathrm{hr}$. The freezer was linked to a data acquisition system (Model D2000; Kimia Rahavard Company, Tehran, Iran) that could be programmed with an accuracy of $\pm 0.3^{\circ} \mathrm{C}$. Thermoelectric signals were recorded by the computer at 6-s intervals and downloaded directly to an Excel spreadsheet (Microsoft Inc., Redmond, WA). The experiment was conducted using a completely randomized design with five replications and three twig segments per plot.

Assessment of tissue viability after controlled freezing. Twigs of cultivars and selections were collected from Nov. 2007 to Jan. 2008, cut into $3-\mathrm{cm}$ pieces, and transferred to the laboratory as previously described. For each sample, three twig segments were wrapped in moistened cheesecloth and placed in a test tube. Test tubes were first submerged into an ethylene-glycol (E-G) bath at $1{ }^{\circ} \mathrm{C}$ for $24 \mathrm{~h}$ to adapt the samples to cold conditions. The E-G bath was programmed to then decrease the temperature by $2^{\circ} \mathrm{C} / \mathrm{h}$ (Khanizadeh, 1991) to freezing temperatures of $0,-5,-10$, $-15,-20,-25$, and $-30{ }^{\circ} \mathrm{C}$ and samples were held at each final temperature for $16 \mathrm{~h}$. Samples of each cultivars and selections were removed at $5{ }^{\circ} \mathrm{C}$ intervals and allowed to thaw at $4 \pm 2{ }^{\circ} \mathrm{C}$ for $24 \mathrm{~h}$. After thawing, samples were removed from test tubes and placed in sterilized petri dishes with water-saturated filter paper and kept in the dark at room temperature $\left(25^{\circ} \mathrm{C}\right)$ for $10 \mathrm{~d}$. Buds and stems were then visually evaluated for injury as previously described (Fuchigami et al., 1971; Sakai and Larcher, 1987). The experiment was conducted using a completely randomized design with five replications and three twig segments per plot for each treatment.

Freeze injury of fully mature trees in orchard. An unprecedented midwinter freeze occurred at the experimental orchard in the winter of 2008 (Table 1) causing injury to twigs and buds of walnut cultivars and selections. Cultivars and selections in this orchard were grafted on Juglans regia L. seedling rootstocks and planted in 1993 in a lattice design with two replications and four trees per plot. The trees have been furrow-irrigated, fertilized with 300 to $400 \mathrm{~g}$ nitrogen per tree during the growing period (late spring), and not treated for pests or diseases since the planting date. To estimate the severity of cold injury, twigs from affected trees were cut in mid-February and transferred to the laboratory, cut into $3-\mathrm{cm}$ pieces, placed in sterilized petri dishes with water-saturated filtered paper, and held in the dark at room temperature $\left(25^{\circ} \mathrm{C}\right)$ for $10 \mathrm{~d}$. Buds and stems were then visually rated for injury. The evaluation was repeated again in April to determine the ability of trees to recover. Tissue browning was used as a visual indicator of injury. Injury was classified using a 1 to 6 injury scale with Class 1 showing no browning and Class 6 the most severe injury. The experiment was conducted in a completely randomized design with five replications and three twig segments per sample.

Statistical analysis. Data were analyzed using SAS Software (SAS Institute, Inc., 2002). Comparisons of means were performed using Duncan's multiple range test at $P \leq$ 0.01 . Student's $t$ test analysis was performed using SPSS 13.0 for Windows (Chicago, IL).

\section{Results and Discussion}

Generation of differential thermal analysis profiles and occurrence of multiple low temperature exotherms. DTA profiles were acquired by comparing measured samples with a reference standard to distinguish exotherms from thermal fluctuation noise of the refrigerator. Typical DTA profiles are shown in Figure 1 with one LTE observed in Nov. 2007 and three LTEs observed in Feb. 2008. The difference in the number of LTEs was correlated with season and is consistent with the previous finding by Ketchie and Kammereck (1987) and Quamme et al. (1972). This difference in seasonal expression of exotherms may be the result of altered cellular ability to prevent ice formation with low resistance in the fall resulting in sudden freezing and increased resistance in midwinter producing gradual freezing. When two or three LTEs occurred, we considered the observation at the lowest of the temperatures to be the critical LTE for survival.

Exotherm differences among tissues and cultivars and selections. Water in both stem and bud tissues froze at two distinct points. In buds, a large exotherm was observed between -0.5 and $-4.9^{\circ} \mathrm{C}$ and a small exotherm occurred between -6 and $-13.9{ }^{\circ} \mathrm{C}$ (Fig. 2). The HTE is likely the result of water freezing in the bud scales (Burke and Stushnoff, 1976; Quamme, 1974). In stem segments, the HTE varied from -1.2 to $-6.3{ }^{\circ} \mathrm{C}$ and the $\mathrm{LTE}$ ranged between -7.8 to $-17.5^{\circ} \mathrm{C}$. Among the promising selections, the buds and stem segments of ' $Z_{63}$ ' and ' $Z_{30}$ ' had the highest and the lowest supercooling points, respectively. Among commercial cultivars, 'Pedro' had the highest supercooling point and 'Serr' the lowest.

Seasonal changes in supercooling ability. The capacity for supercooling of buds and stems increased in all cultivars and selections
Table 1. Minimum and maximum temperatures of an unprecedented freeze at the experimental orchard in Kamal Shahr (a city $50 \mathrm{~km}$ west of Tehran at 1312-m altitude) in the winter (January to February) of 2008.

\begin{tabular}{lcc}
\hline Period & Minimum & Maximum \\
\hline First week & $-15^{\circ} \mathrm{C}$ & $+5{ }^{\circ} \mathrm{C}$ \\
Second week & $-16{ }^{\circ} \mathrm{C}$ & $-3{ }^{\circ} \mathrm{C}$ \\
Third week & $-17^{\circ} \mathrm{C}$ & $-2{ }^{\circ} \mathrm{C}$ \\
Fourth week & $-11^{\circ} \mathrm{C}$ & $+6{ }^{\circ} \mathrm{C}$ \\
\hline
\end{tabular}
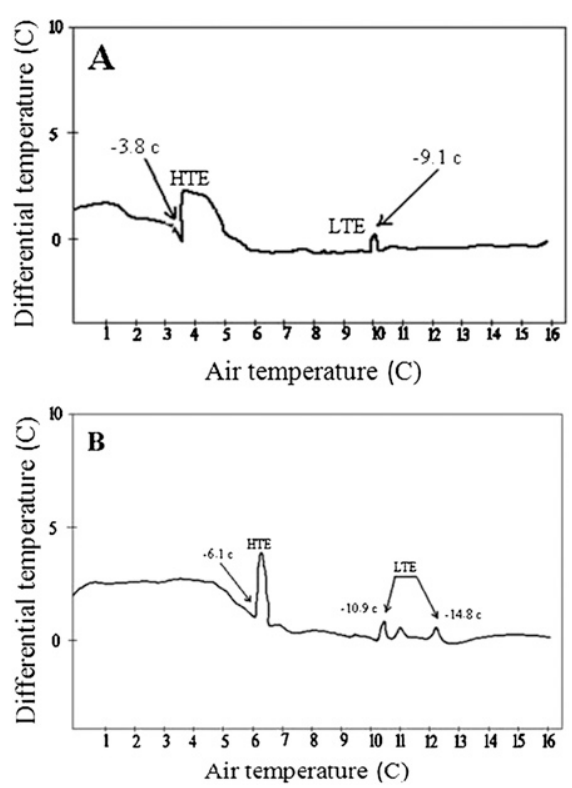

Fig. 1. Differential thermal analysis profile of walnut stem cooled at the rate of $2^{\circ} \mathrm{C} / \mathrm{h}$ in Nov. 2007 (A) and Feb. 2008 (B) indicating one low temperature exotherm (LTE) observed in the fall and three LTEs observed in midwinter. Difference in number of LTEs may reflect the low ability of cells to prevent ice formation in the fall and their increased ability modify freezing rate in midwinter.

with the overall trend of declining temperatures from November through January and February. Buds and stems then lost their ability to supercool as they moved from dormancy to deacclimating and budbreak in March and April (Fig. 2). This phenomenon has been attributed to alteration in pit membrane activity, which plays an important role in preventing intracellular ice formation (Wisniewski and Davis, 1989). In that study, the pectic component of the pit membrane appeared to play a key role in regulating membrane porosity, but unique arabinogalactan-rich glycoprotein was identified, which also may be involved (Wisniewski and Davis, 1995). The possible role of this glycoprotein is suggested by observations that water within small-diameter pores freezes at lower temperature than bulk water or cell walls with low concentrations of this material and consequently broader pores (Ashworth and Abeles, 1984; George and Burke, 1977). Olien (1978) also reported that mucilaginous polymers along the cell wall slow the rate of ice crystal growth and Jian et al. (1987) found glycoprotein accumulation on the outer surface of the cell wall during acclimation. Furthermore, during the acclimation 

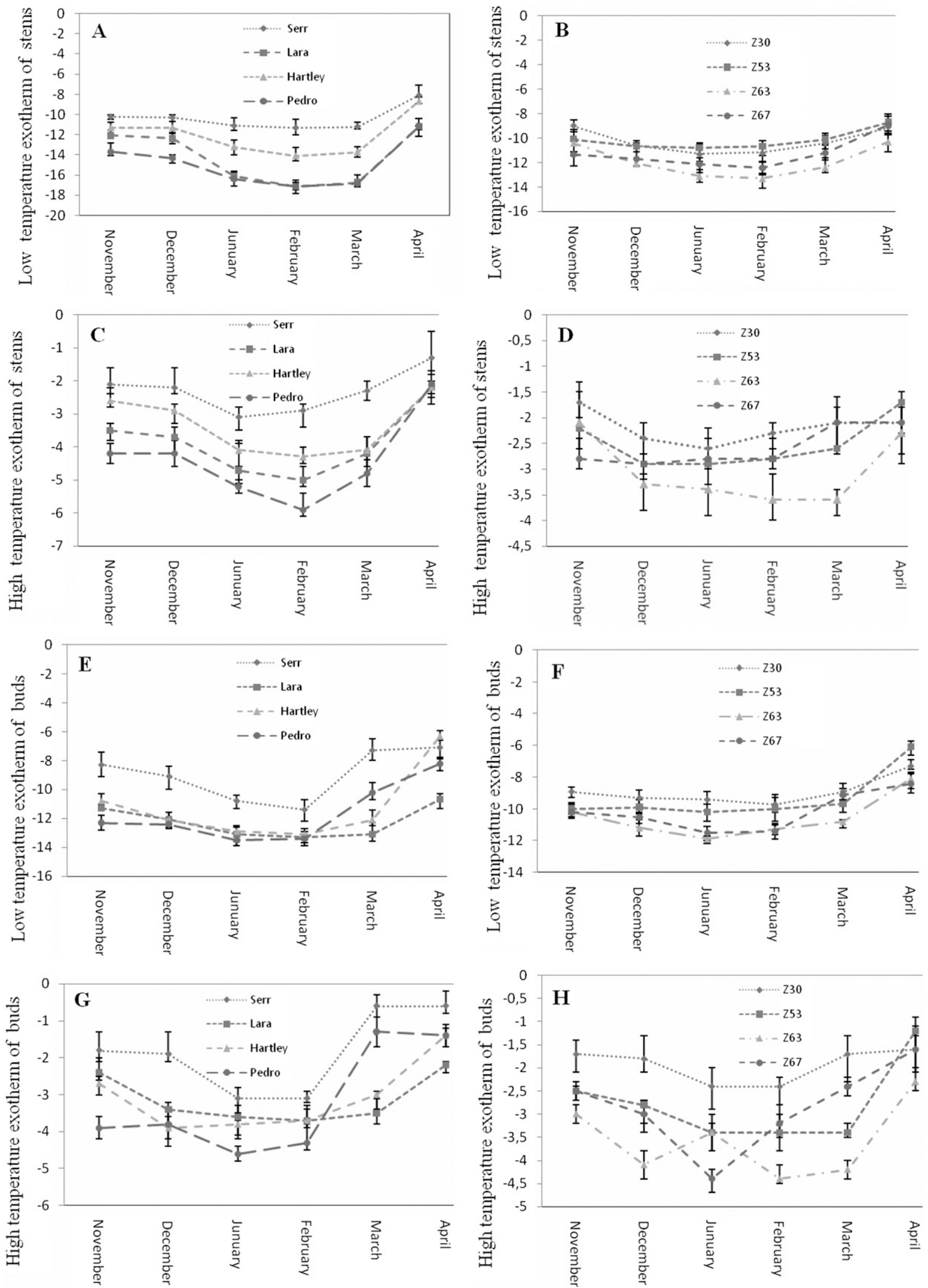

Fig. 2. Variation in high $(\mathbf{C}, \mathbf{D}, \mathbf{G}, \mathbf{H})$ and low $(\mathbf{A}, \mathbf{B}, \mathbf{E}, \mathbf{F})$ temperature exotherms of stems $(\mathbf{A}-\mathbf{D})$ and buds $(\mathbf{E}-\mathbf{H})$ of Persian walnut cultivars and selections indicating that the capacity for supercooling of all cultivars and selections increased with the accumulation of chilling from November through January or February but that buds and stems lost the ability to supercool as they deacclimated from dormancy to budbreak in March and April. Data were acquired by thermal analysis of tissue collected from Nov. 2007 to Apr. 2008. For cases in which two or three low temperature exotherms (LTEs) occurred, we used the lowest temperature observation as the LTE. 
process, the loss of water from cells to prevent ice formation in adjacent tissue is an important factor in preventing the occurrence of the LTE (George and Burke, 1977; Wisniewski et al., 1987).

Comparison of exotherm results with estimated chilling requirements. Chilling and heat requirements of the cultivars and selections used in this study were estimated pre-

Table 2. Estimated chilling (hours below $7{ }^{\circ} \mathrm{C}$ ) and heat requirements $\left(\mathrm{GDH}^{\circ} \mathrm{C}\right)$ of walnut cultivars and selections as calculated based on the Richardson et al. (1974) model using excised twigs in 2 successive years (Aslani Aslamarz et al., 2009).

\begin{tabular}{lcc}
\hline $\begin{array}{l}\text { Cultivars and } \\
\text { selections }\end{array}$ & $\begin{array}{c}\text { Chilling } \\
\text { requirement } \\
\left.\text { (hours below } 7{ }^{\circ} \mathrm{C}\right)\end{array}$ & $\begin{array}{c}\text { Heat } \\
\text { requirement } \\
\left(\mathrm{GDH}^{\circ} \mathrm{C}\right)\end{array}$ \\
\hline $\mathrm{Z}_{30}$ & 650 & 11,503 \\
$\mathrm{Z}_{67}$ & 750 & 12,743 \\
$\mathrm{Z}_{53}$ & 800 & 11,064 \\
$\mathrm{Z}_{63}$ & 900 & 15,186 \\
Serr & 650 & 10,934 \\
Hartley & 1000 & 14,322 \\
Lara & 900 & 12,957 \\
Pedro & 750 & 13,625 \\
\hline
\end{tabular}

GDH $=$ growing degree hours.

Table 3. Temperatures causing lethal injury during controlled freezing to $10 \%, 50 \%$, and $90 \%$ (LT10, LT50, and LT90) of buds of walnut cultivars and selections collected from Nov. 2007 to Jan. $2008 .{ }^{2}$

\begin{tabular}{|c|c|c|c|c|c|c|c|c|c|}
\hline \multirow{2}{*}{$\begin{array}{l}\text { Cultivars and } \\
\text { selections }\end{array}$} & \multicolumn{3}{|c|}{ November } & \multicolumn{3}{|c|}{ December } & \multicolumn{3}{|c|}{ January } \\
\hline & LT10 & LT50 & LT90 & LT10 & LT50 & LT90 & LT10 & LT50 & LT90 \\
\hline Hartley & $-1.6 a^{y} b^{y}$ & $58 \mathrm{~h}$ & & $4.1 \mathrm{ab}$ & $-9.1 \mathrm{~d}$ & $-15 b$ & $-5 b c$ & $-11.6 \mathrm{c}$ & $-20 b$ \\
\hline & & & & & & & & & -23 \\
\hline & & & & & & & & & \\
\hline & & 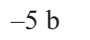 & & & & & -4 & & -1 \\
\hline$z_{30}$ & $-0.8 \mathrm{~b}$ & $-4 b$ & -1 & -1.6 & -10 & -1 & $-5.8 \mathrm{abc}$ & -10 & $-1 c$ \\
\hline 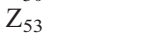 & $-2.5 \mathrm{ab}$ & $-5.8 \mathrm{~b}$ & -10 & -4.1 & $-13.3 \mathrm{c}$ & -15 & $-4.01 \mathrm{c}$ & $-14.1 \mathrm{~b}$ & $-14.1 \mathrm{e}$ \\
\hline 63 & $-1.6 \mathrm{ab}$ & $-5.8 \mathrm{~b}$ & $-11.6 \mathrm{bc}$ & $-3.3 b c$ & $-15 \mathrm{~b}$ & $-18.3 \mathrm{a}$ & $-6.6 a b$ & $-18.3 \mathrm{a}$ & $-20.8 \mathrm{~b}$ \\
\hline$Z_{67}$ & $-3.3 \mathrm{a}$ & $-4.1 \mathrm{~b}$ & $-11.6 b c$ & $-5 a b$ & $-10 \mathrm{a}$ & $-16.6 \mathrm{~b}$ & $-5.8 a b c$ & $-15 b$ & $-18 \mathrm{~cd}$ \\
\hline
\end{tabular}

${ }^{2}$ Each value is the mean of five replications and three twig segments per sample.

${ }^{y}$ Means in each column followed by the same letter are not significantly different according to Duncan's multiple range test $(P \leq 0.01)$.

Table 4. Temperatures causing lethal injury during controlled freezing to $10 \%, 50 \%$, and $90 \%$ (LT10, LT50, and LT90) of stems of walnut cultivars and selections collected from Nov. 2007 to Jan. $2008 .{ }^{2}$

\begin{tabular}{|c|c|c|c|c|c|c|c|c|c|}
\hline \multirow{2}{*}{$\begin{array}{l}\text { Cultivars and } \\
\text { selections }\end{array}$} & \multicolumn{3}{|c|}{ November } & \multicolumn{3}{|c|}{ December } & \multicolumn{3}{|c|}{ January } \\
\hline & LT10 & LT50 & LT90 & LT10 & LT50 & LT90 & LT10 & LT50 & LT90 \\
\hline & $3 \mathrm{~b}^{\mathrm{y}}$ & & $6.6 \mathrm{a}$ & $8 \mathrm{ab}$ & & $-16.6 \mathrm{c}$ & $a b$ & $17.5 \mathrm{c}$ & $23 \mathrm{ab}$ \\
\hline & $5 \mathrm{a}$ & & - & & & & $\mathrm{a}$ & $-23 \mathrm{a}$ & $-25 \mathrm{a}$ \\
\hline & $8 \mathrm{a}$ & -11 & $-16.6 \mathrm{a}$ & $-7.5 \mathrm{a}$ & $-20 \mathrm{a}$ & -24 . & $-7.5 \mathrm{a}$ & $-23 \mathrm{a}$ & -25 \\
\hline CI & $-3.3 \mathrm{~b}$ & -7 & $-12.5 \mathrm{a}$ & $-5.8 \mathrm{~b}$ & $-14.1 b c$ & -17 & -5 & $-15.8 \mathrm{~cd}$ & -16.3 \\
\hline$Z_{30}$ & $-1.6 \mathrm{~b}$ & $-5.8 \mathrm{~d}$ & $-11.6 \mathrm{a}$ & $-5 a b$ & -12 . & $-16.6 \mathrm{c}$ & $-5 \mathrm{~b}$ & $-12.5 \mathrm{e}$ & -13 \\
\hline$Z_{53}$ & $-1.6 \mathrm{~b}$ & $-10 a b$ & $-17.5 \mathrm{a}$ & $-5.8 \mathrm{ab}$ & $-14.1 b c$ & $-16.6 \mathrm{c}$ & $-7.5 \mathrm{a}$ & $-14.1 \mathrm{de}$ & -17.5 \\
\hline$Z_{63}$ & -1.6 & $-8.3 b c$ & $-16.6 \mathrm{a}$ & $-5.8 \mathrm{ab}$ & $-15.8 \mathrm{~b}$ & $-21.6 \mathrm{~b}$ & $-7.5 \mathrm{a}$ & $-20.8 \mathrm{~b}$ & -2 \\
\hline$Z_{67}$ & $-3.3 \mathrm{~b}$ & $-7.5 \mathrm{~cd}$ & $-16.6 \mathrm{a}$ & $-5 \mathrm{~b}$ & $-13.3 \mathrm{c}$ & $-16.6 \mathrm{c}$ & $-5.8 \mathrm{ab}$ & $-15.8 \mathrm{~cd}$ & -19.6 \\
\hline
\end{tabular}

${ }^{\mathrm{z}}$ Each value is the mean of five replications and three cuttings per sample.

${ }^{y}$ Means in each column followed by the same letter are not significantly different according to Duncan's multiple range test $(P \leq 0.01)$. causing lethal freezing injury to $10 \%, 50 \%$, and $90 \%$ of buds or stems as determined by tissue browning), the cultivars and selections studied were classified as sensitive ('Serr' and ' $Z_{30}$ '), semihardy ('Hartley', ' $Z_{63}$ ', ' $Z_{67}$ ', and ' $Z_{53}$ '), or hardy ('Lara' and 'Pedro') (Table 3). The LT50s for buds ranged from -4 to $-9.1^{\circ} \mathrm{C}$ in November and from -10 to $-20{ }^{\circ} \mathrm{C}$ in Jan. The LT50s for stems similarly ranged from -5.8 to $-11.6^{\circ} \mathrm{C}$ in November and from -12.5 to $-23{ }^{\circ} \mathrm{C}$ in Jan. (Table 4). The differences in LT50s between November and January indicate the effect of acclimation in reducing injury to buds and stems. One of the interesting things about the data is that the most sensitive cultivars in November were not necessarily the most sensitive ones in January. For example, ' $\mathrm{Z}_{63}$ ' was among the most sensitive group in November but as acclimation increased, this became one of the more resistant selections by January. This result is consistent with other studies of cold-hardiness (Gu et al., 2000; Wolf and Warren, 2000) and may reflect differences in the timing of entering dormancy in the fall.

Relationship of freeze injury to the high temperature exotherm and low temperature exotherm ranges of buds and stems. The monthly pattern of cold-hardiness, as determined by visual symptoms of tissue injury, was compared with the observed exotherm data (Table 5). Results show that the LT50s and LT10s of both buds and stems were generally between the HTE and LTE, indicating that injury begins at temperatures just below the HTE and that tissue damage is occurring at temperatures above the LTE. The LTE measurements corresponded best with the LT90 data. Similar results were observed with apple (Quamme et al., 1972), shag bark hickory (George and Burke, 1977), hardwood species (Hong et al., 1980), and grape (Mills et al., 2006; Pierquet and Stushnoff, 1980). The range of LT90s extended lower than the range of LTEs in all months, indicating that tissue lethality, as measured by tissue browning, does not always correspond with the LTE (Ashworth et al., 1983; Bartolozzi and Fontanazza, 1999) and that walnut twigs can survive temperatures lower than those indicated by LTE measurement. Note that the range of LT10s of stems was wider in November than in January. Furthermore, the monthly changes in the exotherm temperatures for both buds and stems paralleled changes in sensitivity to freeze injury as measured by tissue browning.

Differences in cold-hardiness and supercooling between buds and stems. Means analyses using Student's $t$ test for differences between buds and stems in 1) supercooling ability and 2) tissue cold-hardiness (LT10,

Table 5. Comparisons of the high and low temperature exotherm (HTE, LTE) ranges to the ranges of 10\%, 50\%, and 90\% lethal temperatures (LT10, LT50, and LT90) for controlled-freezing injury of buds and stems of walnut cultivars and selections collected from Nov. 2007 to Jan. 2008.

\begin{tabular}{|c|c|c|c|c|c|c|c|c|}
\hline \multicolumn{4}{|c|}{ Stems } & & \multicolumn{4}{|c|}{ Buds } \\
\hline Month & & $\begin{array}{l}\text { Range } \\
\text { of LT50 }\end{array}$ & $\begin{array}{c}\text { Range } \\
\text { of LT90 }\end{array}$ & $\begin{array}{l}\text { Range of } \\
\text { HTE-LTE }\end{array}$ & $\begin{array}{l}\text { Range } \\
\text { of LT10 }\end{array}$ & $\begin{array}{l}\text { Range } \\
\text { of LT50 }\end{array}$ & $\begin{array}{c}\text { Range } \\
\text { of LT90 }\end{array}$ & $\begin{array}{l}\text { Range of } \\
\text { HTE-LTE }\end{array}$ \\
\hline November & & -5.8 to -11.6 & -11.6 to -17.5 & -1.7 to -13.7 & -0.8 to -2.5 & -4 to -9.1 & -9.8 to -14.1 & -1.8 to -12.3 \\
\hline December & & -10.8 to -20 & -16.6 to -24.1 & -2.2 to -14.3 & -1.6 to -5.8 & -8.6 to -18.3 & -15 to -20 & -1.9 to -12.4 \\
\hline
\end{tabular}


Table 6. Differences between bud and stem supercooling (high low temperature exotherm) ability among walnut cultivars and selections collected from Nov. 2007 to Apr. 2008.

\begin{tabular}{lccccr}
\hline Paired differences & Mean & SD & SE mean & t value & df \\
$\begin{array}{l}\text { Bud-stem intracellular } \\
\text { ice formation }\end{array}$ & 0.22 & 0.87 & 0.06 & $3.99^{*}$ & 239 \\
Bud-stem extracellular & 1.50 & 1.36 & 0.09 & $17.00^{*}$ & 239
\end{tabular}

ice formation

*Significantly different $(P \leq 0.05)$ according to Student's $t$ test.

Table 7. Differences between bud and stem in the temperatures causing lethal injury during controlled freezing to $10 \%, 50 \%$, and $90 \%$ (LT10, LT50, and LT90) of samples among walnut cultivars and selections collected from Nov. 2007 to Apr. 2008.

\begin{tabular}{lccccr}
\hline Paired differences & Mean & SD & SE mean & t value & df \\
\hline LT10 of buds-LT10 of stems & 1.88 & 2.77 & 0.23 & $8.14^{*}$ & 143 \\
LT50 of buds-LT50 of stems & 1.91 & 3.18 & 0.27 & $7.20^{*}$ & 143 \\
LT90 of buds-LT90 of stems & 2.50 & 3.18 & 0.27 & $9.42^{*}$ & 143 \\
\hline
\end{tabular}

*Significantly different $(P \leq 0.05)$ according to Student's $t$ test.

Table 8. Evaluation of frost injury to buds and stems of walnut cultivars and selections caused by an unprecedented freeze in midwinter 2008 and recovery from injury in Apr. 2008. ${ }^{\mathrm{z}}$

\begin{tabular}{lccccc}
\hline \multirow{2}{*}{$\begin{array}{l}\text { Cultivars and } \\
\text { selections }\end{array}$} & $\begin{array}{c}\text { Injury index } \\
\text { of stems }\end{array}$ & $\begin{array}{c}\text { Injury index } \\
\text { of buds }\end{array}$ & & \multicolumn{2}{c}{ April } \\
\cline { 2 - 3 } Hartley & 2 & 3 & 1 & $\begin{array}{c}\text { Injury index } \\
\text { of stems }\end{array}$ \\
Lara & 3 & 3 & 2 & 2 \\
Pedro & 2 & 3 & 2 & 1 \\
Serr & 4 & 5 & 3 & 2 \\
$Z_{30}$ & 4 & 5 & 2 & 2 \\
$Z_{53}$ & 3 & 3 & 1 & 2 \\
$Z_{63}$ & 2 & 4 & 3 & 2 \\
$Z_{67}$ & 3 & 4 & 3 & 2 \\
\hline
\end{tabular}

${ }^{z}$ Tissue browning was used as a visual indicator of injury and was scored on a 1 to 6 scale. Class 1 showed no browning and Class 6 the most severe injury.

LT50, and LT90) are presented in Tables 6 and 7, respectively. Results show that by both measures, stems were significantly more coldtolerant than buds. This is consistent with the findings of Irving and Lanphear (1967) who demonstrated that dormancy and cold-hardiness development in stems are independent of bud dormancy.

Field observation of cold damage under natural conditions. A severe midwinter freeze caused various degrees of injury to buds and stems of the cultivars and selections examined (Table 8). The greatest injury was observed in 'Serr' and ' $Z_{30}$ ', whereas the least injury was found in the buds and stems of 'Hartley', 'Pedro', and ' $\mathrm{Z}_{63}$ '. In all cultivars except 'Lara', the injury under natural conditions was well correlated with laboratory results as has been seen in other woody plants (Pellett et al., 1981; Sakai et al., 1986).

Our observations indicate that signs of injury to stems and buds had decreased considerably by April (Table 8). The recovery process after freeze injury requires chemical energy for $\mathrm{H}^{+}$-ATPase mediated reuptake of leaked ions into cells against a concentration gradient (Palta and Weiss, 1993). Reuptake is followed by reabsorbing of water (Arora and Palta, 1991). These changes revitalize the cells and may explain why fewer injury symptoms were observed in the spring.

In conclusion, results from the exotherm studies, evaluation of tissue injury under controlled freezing, and observations of material frozen under field conditions all showed that
'Pedro', 'Hartley', and ' $\mathrm{Z}_{63}$ ' may be appropriate for cultivation in regions where midwinter cold is a concern. 'Serr' and ' $Z_{30}$ ' exhibited the least cold-hardiness among cultivars and selections tested and appeared to be less suitable for such climates. Frost injury of walnut is influenced by three factors: the time of entering dormancy, the time of budbreak, and the midwinter cold-hardiness of the selections. It should be noted that 'Pedro', despite its high degree of midwinter cold-hardiness, is in the group of cultivars requiring only a moderate amount of chilling and heat units before budbreak. For regions with late winter or early spring frosts, this cultivar could be replaced with cultivars such as 'Hartley', 'Lara', or ' $\mathrm{Z}_{63}$ '. Breeding programs seeking walnut cultivars adapted to cold climates should consider using cultivars and selections with a high degree of midwinter hardening such as 'Pedro', 'Hartley', 'Lara', and ' $\mathrm{Z}_{63}$ ' as parents.

\section{Literature Cited}

Andrews, P.K. and E.L. Proebsting. 1987. Effects of temperature on the deep supercooling characteristics of dormant and deacclimating sweet cherry flower buds. J. Amer. Soc. Hort. Sci. 1123:334-340.

Arora, R. and J.P. Palta. 1991. A loss in the plasma membrane ATPase activity and its recovery coincides with incipient freeze-thaw injury and post thaw recovery in onion bulb scale tissue. Plant Physiol. 95:846-852.

Ashworth, E.N. 1992. Formation and spread of ice in plant tissues. Hortic. Rev. (Am. Soc. Hortic. Sci.) 13:215-225.
Ashworth, E.N. and F.B. Abeles. 1984. Freezing behavior of water in small pores and the possible role in the freezing of plant tissue. Plant Physiol. 76:201-204.

Ashworth, E.N., D.J. Rowse, and L.A. Billmyer. 1983. The freezing of water in woody tissue of apricot and peach and relationship to freezing injury. J. Amer. Soc. Hort. Sci. 108:299-303.

Aslani Aslamarz, A.A., K. Vahdati, M. Rahemi, and D. Hassani. 2009. Estimation of chilling and heat requirement of some Persian walnut cultivars. HortScience 44:697-701.

Bartolozzi, F. and G. Fontanazza. 1999. Assessment of frost tolerance in olive. Sci. Hort. 81: 309-319.

Bierman, J., C. Stushnoff, and M.J. Burk. 1979. Differential thermal analysis and freezing injury in cold hardy blueberry flower buds. J. Amer. Soc. Hort. Sci. 104:444-449.

Burke, M.J., L.V. Gusta, H.A. Quamme, C.J. Weiser, and P.H. Li. 1976. Freezing injury in plants. Annu. Rev. Plant Physiol. 27:507-528.

Burke, M.J. and C. Stushnoff. 1976. Frost hardiness: A discussion of possible molecular cause of injury with particular reference to deep supercooling of water, p. 197-225. In: Mussell, H. and R.C. Staples (eds.). Stress physiology in crop plants. Wiley, New York, NY.

Dunner, E.F. and T.J. Gianfagna. 1991. Peach pistil carbohydrate and moisture contents and growth during controlled deacclimation following ethephon application. J. Amer. Soc. Hort. Sci. 116: 507-511.

Faust, M. 1989. Physiology of temperate zone fruit trees. Wiley- Interscience, New York, NY.

Fuchigami, L.H., C.J. Weiser, and D.R. Evert. 1971. Induction of cold acclimation Cornus stolonifera Michx. Plant Physiol. 47:98-103.

Fujikawa, S. and K. Kuroda. 2000. Cryo-scanning electron microscopic study on freezing behavior of xylem ray parenchyma cells in hardwood species. Micron 31:215-255.

George, M.F. and M.J. Burke. 1977. Cold hardiness and deep supercooling in xylem of shagbark hickory. Plant Physiol. 59:319-325.

George, M.F., H.M. Pellett, and A.G. Johnson. 1974. Low temperature exotherms and woody distribution. HortScience 9:519-522.

Gu, S., K.L. Wilker, M.R. Dharmadhikari, J.F. Moor, S. Howard, C.E. Edson, T.M. Bonney, and M.K. Walsh. 2000. Evaluation of grapevine cultivars and breeding lines for ability to Missouri conditions. Acta Hort. 528:569-574.

Gusta, L.V., M. Wisniewski, N.T. Nesbitt, and K.T. Tanino. 2003. Factor to consider in artificial freezes tests. Acta Hort. 618:493-507.

Hong, S.G., E. Sucoff, and O.Y. Lee-Stadelmann. 1980. Effect of freezing deep supercooled water on the viability of ray cells. Bot. Gaz. 141:464 468.

Howett, E.W., K. Young, E.L. Proebsting, and H.H. Mills. 1978. Modification of critical freezing temperatures in fruit buds by elevated tissue water content. HortScience 13:247-249.

Irving, R.M. and F.O. Lanphear. 1967. Environmental control of cold hardiness in woody plants. Plant Physiol. 42:1191-1196.

Jian, L.C., L.H. Sun, and D.L. Sunday. 1987. Glycoproteins at the cell surface in cold hard and cold tender wheat (Triticum asetivum), $\mathrm{p}$. 59-66. In. Li, P.H. (ed.). Plant cold hardiness. Alan R. Liss, New York, NY.

Ketchie, D.O. and R. Kammereck. 1987. Seasonal variation of cold resistance in Malus woody tissue as determined by differential thermal-analysis and viability test. Can. J. Bot. 65:2640-2645.

Khanizadeh, S. 1991. Controlling temperature by microcomputer. HortScience 26:607. 
Lapins, K. 1961. Artificial freezing of 1-year-old shoots of apple varieties. Can. J. Plant Sci. 41: 381-393.

Lu, S. 1992. Factors related to freezing resistance in peach flowers. PhD diss., Univ. Georgia, Athens, GA.

Malone, S.R. and E.N. Ashworth. 1991. Freezing stress response in woody tissues observed using low-temperature scanning electron microscopy and freeze substitution techniques. Plant Physiol. 95:871-881.

Mills, L.J., J.C. Ferguson, and M. Keller. 2006. Coldhardiness evaluation of grapevine buds and cane tissues. Amer. J. Enol. Viticult. 57:194-200.

Olien, G.R. 1978. Analyses of freezing stress and plant response in plant cold hardiness and freezing stress, p. 37-38. In: Li, P.H., C.R. Olien, and A. Sakai (eds.). Plant cold hardiness and freezing stress. Academic Press, New York, NY.

Palta, J.P. and L.S. Weiss. 1993. Ice formation and freezing injury: An overview on the survival mechanisms and molecular aspects of injury and cold acclimation in herbaceous plants, p. 143-176. In: Li, P.H. and L. Christersson (eds.). Advances in plant cold hardiness. CRC Press, Inc., Boca Raton, FL.

Parker, J. 1963. Cold resistance in woody plants. Bot. Rev. 229:124-201.

Pellett, H., M. Gearhart, and M. Dirr. 1981. Cold hardiness capability of woody ornamental plant taxa. J. Amer. Soc. Hort. Sci. 106:239-243.

Pierquet, P. and C. Stushnoff. 1980. Relationship of low temperature exotherms to cold injury in
Vitis ripara Michx. Amer. J. Enol. Viticult. 31: $1-6$.

Pierquet, P., C. Stushnoff, and M.J. Burk. 1977. Low temperature exotherms in stem and bud tissues of Vitis ripara Michx. J. Amer. Soc. Hort. Sci. 102:54-55.

Quamme, H., C. Stushnoff, and C.J. Weiser. 1972. The relationship of exotherms to cold injury in apple stem tissues. J. Amer. Soc. Hort. Sci. 97:608-613.

Quamme, H.A. 1974. An exothermic process involved in freezing injury to flower buds of several Prunus species. J. Amer. Soc. Hort. Sci. 99:315317.

Quamme, H.A. 1978. Mechanism of supercooling in overwintering peach flower buds. J. Amer. Soc. Hort. Sci. 103:57-61.

Quamme, H.A., W.A. Su, and L.J. Veto. 1995. Anatomical features facilitating supercooling of flower within the dormant peach bud. J. Amer. Soc. Hort. Sci. 12:814-822.

Richardson, E.A., S.D. Seeley, and D.R. Walker. 1974. A model for estimating the completion of rest of 'Redhaven' and 'Elberta' peach trees. HortScience 9:331-332.

Rodrigo, J. 2000. Spring frost in deciduous fruit trees. Morphological damage and flower hardiness. Sci. Hort. 85:155-173.

Sakai, A., L. Fuchigami, and C.J. Weiser. 1986. Cold hardiness in the genus Rhododendron. J. Amer. Soc. Hort. Sci. 111:273-280.

Sakai, A. and W. Larcher. 1987. Frost survival of plants: Responses and adaptation to freezing stress. Ecological studies. Vol. 62. SpringerVerlag, Berlin, Germany.
SAS Institute, Inc. 2002. SAS User's guide: Statistics. Version 9.1. Cary, NC.

Stergios, B.G. and G.S. Howell. 1973. Evaluation of viability tests for cold stressed plants. J. Amer. Soc. Hort. Sci. 98:325-330.

Takeda, F., R. Arora, M.E. Wisniewski, G.A. Davis, and M.R. Warmund. 1993. Assessment of freeze injury in 'Boskoop Giant' black currant buds. HortScience 28:652-654.

Wisniewski, M. and R. Arora. 2000. Structural and biochemical aspects of cold hardiness in woody plants, p. 419-438. In: Jain, S.M. and S.C. Minocha (eds.). Molecular biology of woody plants. Vol. 2. Kluwer Academic Publ., Dordrecht, The Netherlands.

Wisniewski, M.E.A. and K. Schaffer. 1987. The use of lanthanum to characterize cell wall permeability in relation to deep supercooling and extracellular freezing in woody plants Intrageneric comparisons between betula lenta and betula papyrifera. Protoplasma 141:160 168.

Wisniewski, M. and G. Davis. 1989. Evidence for the involvement of specific cell wall layer in the regulation of deep supercooling of xylem parenchyma. Plant Physiol. 139:105-116.

Wisniewski, M. and G. Davis. 1995. Immunogold localization of pectin and glycoprotein in tissues of peach with reference to deep supercooling. Trees (Berl.) 9:253-260.

Wolf, T.K. and M.K. Warren. 2000. Crop yield and quality and winter injury of eight wine grape cultivars in northern Virginia. J. Amer. Pomol. Soc. 54:34-43 